\title{
The Authorising Function of Budgets in Public Administration. Applicability of IPSAS 24 in Italy
}

\author{
Fabio Giulio Grandis ${ }^{1}$, Giorgia Mattei ${ }^{2}$ \\ ${ }^{1}$ Department of Business Studies, Management and Accounting of Public Administration, "Roma Tre" \\ University, Roma, Italy \\ ${ }^{2}$ Department of Business Studies, "Roma Tre" University, Roma, Italy \\ Email: fg.grandis@studioferrari.com, giorgia.mattei@uniroma3.it
}

Received 6 December 2013; revised 15 January 2014; accepted 31 January 2014

Copyright (C) 2014 by authors and Scientific Research Publishing Inc.

This work is licensed under the Creative Commons Attribution International License (CC BY). http://creativecommons.org/licenses/by/4.0/

(c) (i) Open Access

\begin{abstract}
This paper begins with the assumption that in many public administrations, budgets are not limited to the role of mere statements to provide additional information; they are authorisations with a legal value that make them autonomous documents. Our aim was therefore to analyse the relations between politicians and managers, focusing in particular on the governance models in use within public administration in Italy and the role of budgeting in these cases. We have also looked at the contents and constraints of IPSAS 24, from which the difficulties of its application in Italy have emerged. Our research has led to a firm belief that IPSAS 24 needs to be supplemented by an international standard specifically dedicated to budgeting. Moreover, this should include a European version which takes into account SEC 95 and the COFOG classification.
\end{abstract}

\section{Keywords}

Budget, Authorising Function, IPSAS 24, Public Administration Accounting

\section{Introduction}

The work carried out by the International Public Sector Accounting Standards Board IPSASB (ex Public Sector Committee PSC) was, until 2002, to adapt IAS accounting principles to the public sector. Subsequently, from 2002 onwards, specific principles began to be drawn up for those areas in which IAS principles could not be applied in the light of the specific nature of the public sector: for example, in December 2006, IPSAS 24 was rolled out for the presentation of budget information in financial statements. 
During this second stage, a strong attachment to the IAS framework led the IPSAS Board to choose to consider budget information exclusively for the purposes of comparison with the information contained in financial statements, in the same way as for private businesses. This framework does not take into consideration the fact that in the majority of public administrations, budgets have a fundamental role in the process of governance, representing the authorisation granted by the political body to the top management for the use of public resources.

The main aim of this paper consists of assessing whether or not IPSAS 24 is suited to public administrations in which budgeting also plays an authorisation role, or if it should be integrated and if so, the information that will be needed.

The second aim of the research lies in checking the role of budgets in the relations established between political bodies and top management, with a specific eye to what has been happening in Italy's public administration over the last 20 years and specifically, in the recent process of accounting harmonisation for public accounts, as envisaged by the Italian Constitution.

The methodology used for this paper is both deductive and inductive.

The deductive method is used for the most part to achieve the first aim and for some areas of the second. Specifically, the intention is to proceed with a careful critical appraisal of IPSAS 24 and then to outline the governance relationships between political bodies and the top management of any public administration.

The inductive method has mainly been used for the second aim of this paper. Looking at the established cases that can be found in Italian public administration, in their regulation of financial statements and programming, as well as the actual governance methods in place, it is possible to see whether or not they provide evidence for the findings of the doctrinal analysis.

This analysis has revealed obvious difficulties for public administrations and agencies with regard to applying IPSAS for two sets of reasons:

- The first, which also can apply at international levels, concerns the lack of a specific accounting principle for drawing up a budget, which is not analysed as an autonomous document, but exclusively as a function of the information to be provided during the reporting process.

- The second, which is specific to all public administrations in those countries where budgeting has an authorising role.

A public administration budget is more than a management tool as it is in the private sector; above all, it is the cornerstone of relations between political bodies and top-management, as well as between financial and beneficiary administrations.

The turbulent nature of the context in which European public administrations operate, as well as the recent experience concerning the failure to pass the European Union budget should encourage the IPSASB to draw up a specific accounting principle that would give due consideration to the nature of both the different public administrations and governance models in each country as well as within international organizations themselves [1]-[5].

A healthy policy would impose a suitable process for planning, scheduling and budgeting, not just at macroeconomic level, but also within individual public administrations.

\section{The Governance Models and the Role of Budgets in Italian Public Administrations}

In public administration, people operating within the organization and collaborating in the achievement of its targets can be divided into two distinct groups [6] [7]:

- politicians, directly or indirectly appointed by citizens via the electoral system in each individual country; these persons are given the task of defining the main aims and strategic management directions of the entity concerned [8];

- employees, i.e., management and employees working in technical or professional capacities within public administrations, according to an employment contract; their assigned tasks differ according to their respective positions.

Therefore, the organization of any public administration, just like in any private business, requires that the role of each individual be defined, as well as the organizational relations between those individuals [9]. It is also necessary for each manager to be assigned a budget that quantifies the economic and financial resources needed to perform the assigned role [10]. 
In modern and democratic structures, however, the relationship between politics and administration is characterised by a basic tension between two "absolute values" which are unavoidably and physiologically in conflict with one another [11]:

- the principle of popular sovereignty, which involves the political responsibility of those elected by a majority to lead public administration;

- the principle of an administration's impartiality, which establishes that public services for should be provided equitably, for the collective good and not merely for those who elected the political figures.

The role of the public manager falls somewhere between these two values-between a rock and a hard place. Specifically, managers in direct contact with politicians, on the one hand, need to fall in line with policy, while, on the other, need to operate correctly, fairly and cost effectively [12].

The result is a need to identify an organizational model for public administration and budgeting systems that branch out of this conflict and at the same time, safeguard and make capable "public managers" responsible.

In some states, including Italy, legislators have not bothered to find a balance between the principle of popular sovereignty and that of an administration's impartiality; rather, they have sought to achieve both by working on two different variables at the same time [13]:

- the distribution of power between politicians and managers;

- the nature of the employment contracts of managers.

With regard to the variables considered, it is possible to identify four categories of organizational models, as shown in Figure 1.

The "spoil system model" should, in theory, fully safeguard the people's sovereignty since power is mostly assigned to democratically elected political bodies that use managers, bound to the administration by a permanent employment contract or in any case, an agreement founded on the introduction of a "fiduciary" bond, similarly to private businesses. This model can be found in democracies where their constitution places the principle of popular sovereignty above all others. In these administrations, the top management is highly politicised and changes according to the politicians in power. The principle of the administration's impartiality is safeguarded by control systems, and laws which are in any case, subordinate to popular sovereignty.

At the other end of the spectrum is the "technocratic model" which should fully guarantee an administration's impartiality. Giving wide-reaching powers to highly skilled technical and professional managers should lead to correct and fair economic management in the interests of the entire collectivity being administered. A stable working relationship allows management not to fall under the influence of political bodies that continue to represent a majority. This model is found in those administrations with no political alternatives or where a single current of thought prevails, at times imposed by bodies outside the public administration. In these cases, an administration's presumed impartiality is considered the very expression of popular sovereignty.

There are two further models that, with the aim of safeguarding both principles, are in intermediate but completely opposing positions: a "bureaucratic" and a "managerial" model.

The "bureaucratic model" is constructed seeking to give maximum impetus to:

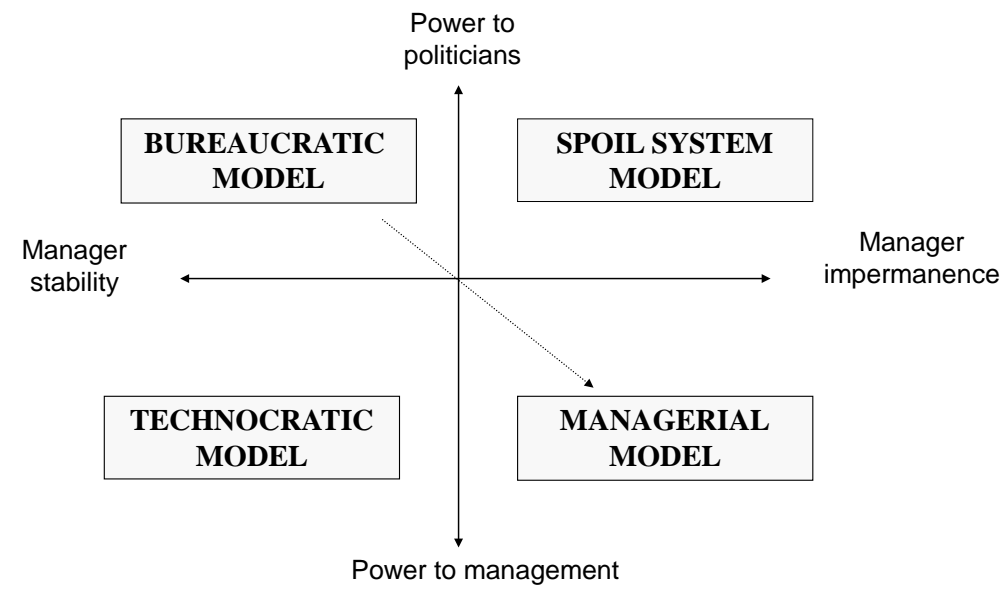

Figure 1. The classification of organizational models [14]. 
- the principle of popular sovereignty, via a distribution of power and responsibilities which favours political agencies;

- the principle of the impartiality of an administration, envisaging an employment contract for managers as a means of guaranteeing stability.

In organizational terms, this model means that the political body is also at the top of the administrative structure [15] and as such, it can boast a hierarchical relationship over management and all operational staff. At the same time, management is protected against political interference, both when hired and during its operations. In fact, management is appointed based on public competitions and each member is hired on a permanent basis, without being removed unless there is a serious reason provided for by law.

The "bureaucratic model" [16] has shortcomings that continue to grow as the functions performed by public administration become more extensive and complex. Thus, the political body loses power as it is no longer able to exercise effective control over decisions taken by managers who, since they are equipped with specific technical skills, are able to impose their own decisions, even if these sometimes go against legitimate political choices.

The "managerial model", on the other hand, is built to give the maximum impetus to:

- the principle of impartial administration, by using the distinction between political positions and management powers;

- the principle of popular sovereignty, by changing the nature of managers' employment contracts, characterised by greater flexibility and introducing a trust-based relationship with political agencies.

This "distinction" between politicians and managers leads, on an organizational level, to the allocation of different and distinct positions, powers and responsibilities: politicians represent the people on account of democratic rules, while managers are at the top of the organizational structure on account of their technical and professional skills. What this means is that an organizational mechanism which is based on the twin tracks of managerial "independence and responsibility" and political "direction and responsibility" is put in place [17].

For the purpose of giving a practical "distinction" however, it is necessary to equip political bodies with suitable tools for directing and overseeing the work of managers. This is the context in which budgeting needs to have an authorising function, both as a means to direct policy and strategy and as a legal means of regulating contractual relations with management.

In the managerial model, the relationship between politicians and management is not based on a hierarchy but on "trust". Consequently, the stability of a manager's position is not guaranteed by law or contractual safeguards, but essentially by a manager's ability to respect the constraints and targets defined in the planning, scheduling and budgeting process [18].

Nonetheless, managers must refuse to follow policy directions if they consider that these go against regulations, cost-effectiveness and fair management. Managers have the power to take operational decisions and to organise management activities exclusively, as well as the means and resources to be used within the limits set by politicians in the budgeting process [19]. In this model managers are answerable for their work in terms of both managerial and legal responsibility.

In this sense, a budget is not just a management tool; it is also a legal one, created and imposed by legislators in order to:

- guarantee respect for political aims, the expression of popular sovereignty;

- assess managers according to their skills and to their technical and professional abilities, making it possible to quantify bonuses and sanctions, including the potential removal from a post if necessary.

Unfortunately, it is undeniable that in the short term, this model may lead to a policiticisation of top-level civil servants. However, it is also true that, at least in the medium-long term, poor managers will remain in their jobs for only as long as the political body that appointed them, while capable managers will keep their jobs as this is also in the interests of the political body [20].

In theory, therefore, this should trigger virtuous mechanisms that, when applied, would raise levels of correctness, cost effectiveness and fairness within public administrations [21].

Following the reform of $1993^{1}$ the governance model in use within the Italian public administration seems to be based on the "managerial model" described above, with some rigidity caused by the cultural heritage of the political classes and to a failure to renew the managerial classes.

\footnotetext{
${ }^{1}$ We refer, in particular to the public employment reform brought into being with Legislative Decree 29/1993, to date incorporated in Legislative Decree 165/2001.
} 
This reform has doubtless added to the content and importance of the budget and financial statement, which are now a powerful means of political control over top managers, since [22]:

- during the estimate stage, the budget is a prior authorisation and at the same time, a constraint on the activities of managers;

- during the accounting stage, the statement serves to audit whether or not political directions and targets have been pursued and achieved while remaining within the set limits.

Increased management autonomy and responsibility should create conditions for increased productivity, intervening directly on organizational and bureaucratic dysfunctions, waste and production inefficiencies [23].

At the same time, the authorising function of financial and economic budgets obliges political bodies to focus on their own functions and on their political responsibilities, i.e., on the definition of those targets that best embody the public interest [24].

Nonetheless, the activities of public administrations are performed using resources mandatorily taken from the public and therefore, suitable regulations must be in place to prevent those resources from being used for activities that do not meet the institutional aims of the administration.

By using this "managerial" model, the reform of accounting systems within the Italian public administration has been faced with the inevitable need to bring the authorising function-which is necessary to legitimise those who manage the "res publica"-into line with the urgent need for management information on costs, performance and the results of public activities [25].

This "organizational" reform has led to the redefinition of the budget's authorising function as a means to regulate relations between politicians and public managers [26].

The authority of political bodies over top management involves dividing the traditional budget into two documents: a more summarised version, for political authorisation and a more analytical one to provide a basis for management to carry out its tasks.

The first document, the "political" or "decisional" budget, translates the relationships between the different political bodies into accounting terms. In fact, in all administrations it is possible to identify at least one "elected" political body and a "governing" one. This document has, in the first instance, an authorising function between elected and governing political bodies, in the same way as a strategic plan in a private business.

The second document, on the other hand, brings together the targets and the resources that the "governing" political bodies allocate to top management; this means that it has the typical functions of the "operational" or "management” budget.

This latter document has a lower level of authorisation compared to the "political budget" account and together with the organizational divisions, it serves to give a firmer distinction between politicians and managers (see Figure 2).

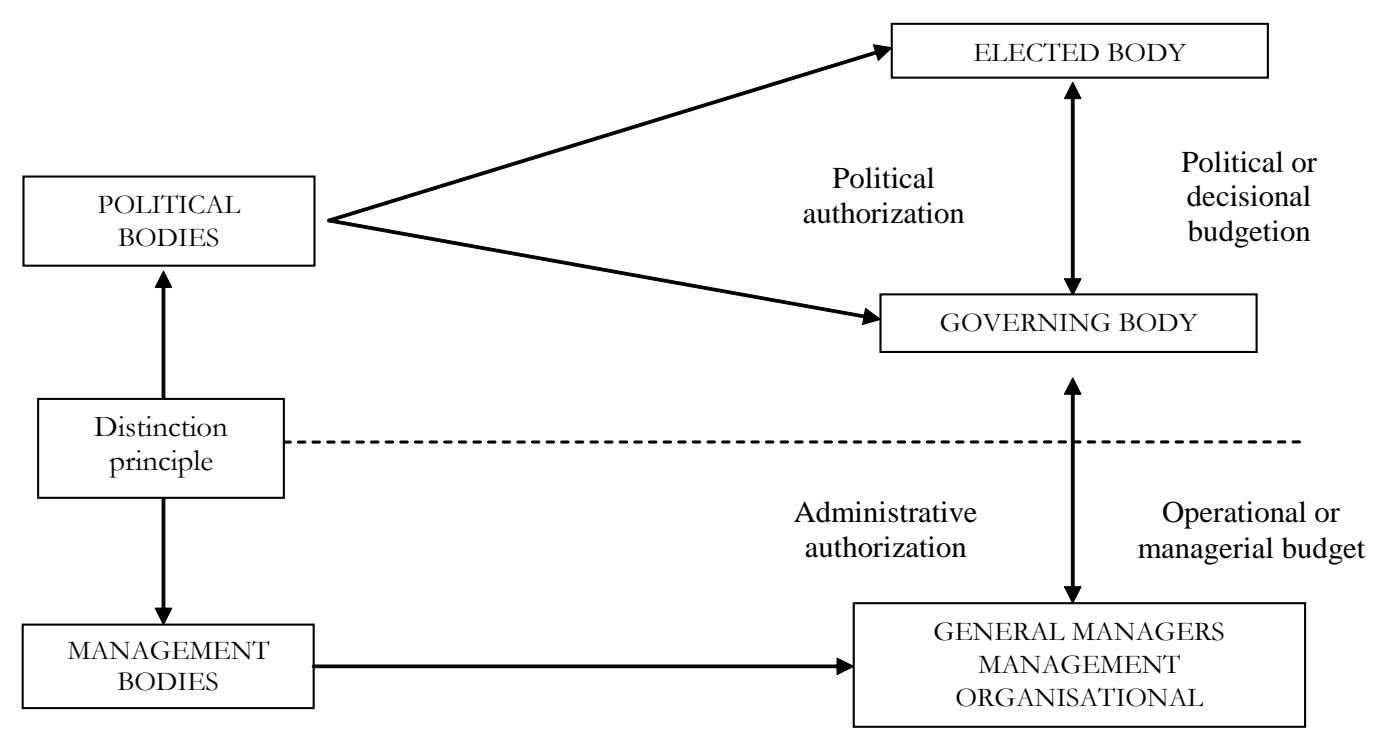

Figure 2. The "distinction" of the authorising function. 
Splitting the traditional budget into two documents with different authorising values has also led to a review of the classification criteria for outgoings so as to put in place a parallel framework between accounting and organizational structures: this means identifying accounting data to show the overall financial resources assigned to a specific sector of the administration to carry out specific operational projects.

In other words, public administrations need to draw up suitable documents to show the degree of achievement of their targets, the progress of their activities and their related use of resources [27].

Looking at the different types of public administration in Italy and the relevant situation of political bodies compared to management bodies, three different organizational models emerge [28]:

- political bodies and management bodies belonging to the same administration;

- political bodies in both higher and subordinate administrations;

- political bodies only present in higher administrations, management bodies are only present in subordinate administrations.

The following is a brief analysis of the three models. It identifies the type of Italian public administration for each model and sets out the role of the budget in each respective accounting system.

A) Political bodies and management bodies belonging to the same administration (see Figure 3).

This model applies to the State and to regions and local bodies. The accounting systems for these administrations comply with the typical logic of "cameral accounting"2 [29], while "accrual accounting" was introduced purely for information and support purposes ${ }^{3}$.

However, in all of these bodies, the "cameral accounting" has been significantly reformed, with several new elements having been introduced to highlight management powers. Such elements include:

- allocating resources to the organizational units responsible for resource management;

- raising the authorising threshold, which is no longer a single accounting item but covers the group of resources for a project;

- splitting the traditional budget into two estimates: a "political" one approved by the elected body and an "operational" one decided upon by the governing body.

- for the purposes of this research, it is important to underline that the splitting of the budget into two estimates has highlighted its authorising function, and requires a redefinition of approval procedures for forecasts at the start of the year as well as the methods that will be used to change them during the course of annual management.

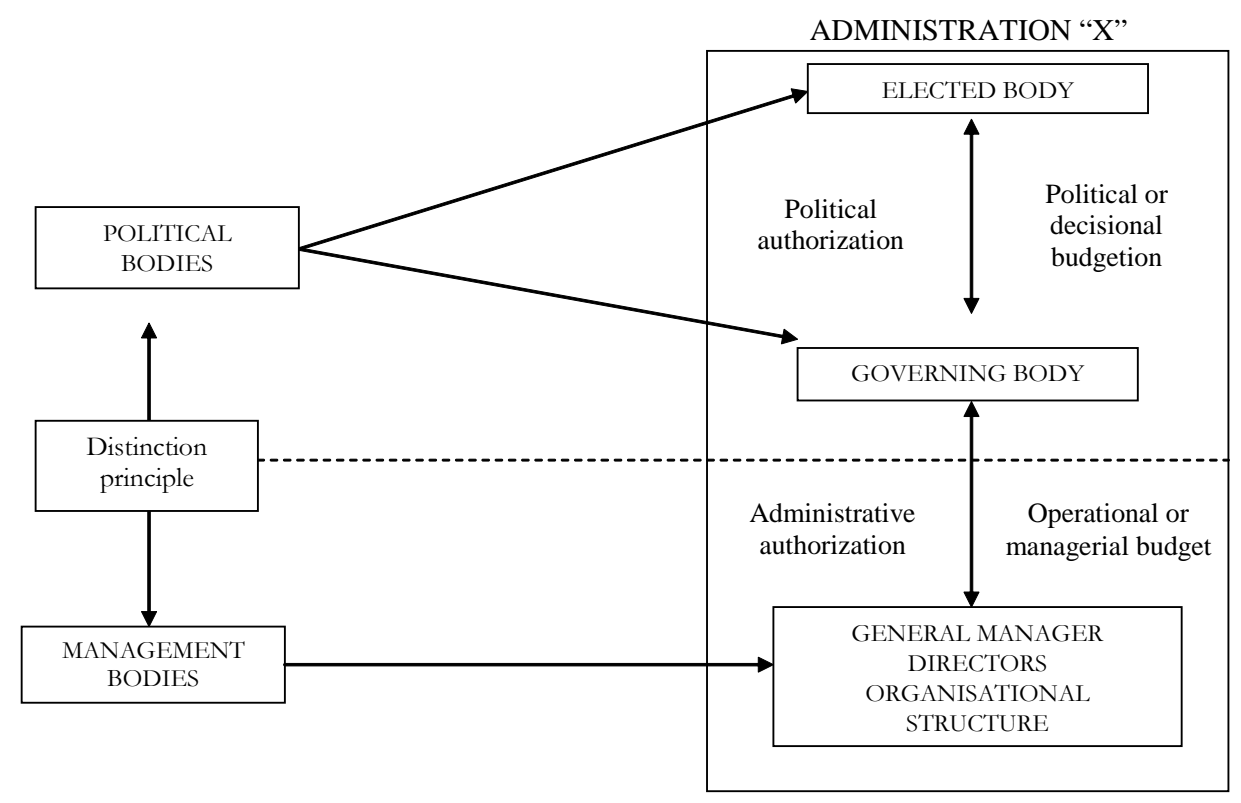

Figure 3. The "distinction" of the authorising function in a single administration.

\footnotetext{
${ }^{2}$ The accounting system that is known in Italy as "accrual accounting” is also known in international studies as "cameral accounting".

${ }^{3}$ See L. 196, art. 2, section 2, subsection d). Regions and local bodies were subsequently subjected to D.Lgs.118/2011 which included a period of experimentation regulated by DPCM 28 December 2011.
} 
B) Political bodies in both higher and subordinate administrations (see Figure 4).

This model, which is typical of almost all subordinate administrations, such as national and regional public bodies, is not substantially different from the previous one, to the extent that the "distinction" between politicians and managers falls within a single administration. However, within that administration there is only a governing body-often referred to as the "Board of Directors". Moreover, this body is almost always appointed by the elected body in the higher or supervisory administration.

Very often, a subordinate administration's financial dependence is so high as to fully justify the authorising function of a budget as seen in "cameral accounting".

However, in Italy, some subordinate administrations have completely abandoned "cameral accounting" in favour of the "accrual accounting" in use in the private sector.

It is well known that accounting regulations for private companies do not require a budget to be drawn up. In these companies, the budget is an optional document, drawn up for in-house management purposes, and is sometimes confidential, since it reflects company strategies that the competition is not to know about. In public administration, however, the budget is a mandatory document that needs to be available to all, as it expresses the choices made by democratically elected politicians. For this reason, the accounting harmonisation process in Italy has imposed the use of an "accruals budget" "also on public administrations, which have accounts that are the same as those of private companies. That budget is typically a "political budget", which follows the "balance sheet" framework and constitutes the instrument by which the "elected" political body authorises the "governing" political body. The latter then draws up an "operational budget" to give to management.

C) Political bodies only present in higher administrations, management bodies are only present in subordinate administrations (see Figure 5).

This case is typical of national health service bodies, authorities, and government agencies. These "companies" are expressly included in the idea of public administration, both from a regulatory point of view ${ }^{5}$ and in management terms.

In these administrations, the topmost echelon of the body is a general manager. The "distinction" between politicians and managers also marks the confine between "higher" and "subordinate" administrations. This means that political dynamics only show up "above and beyond" the individual body.

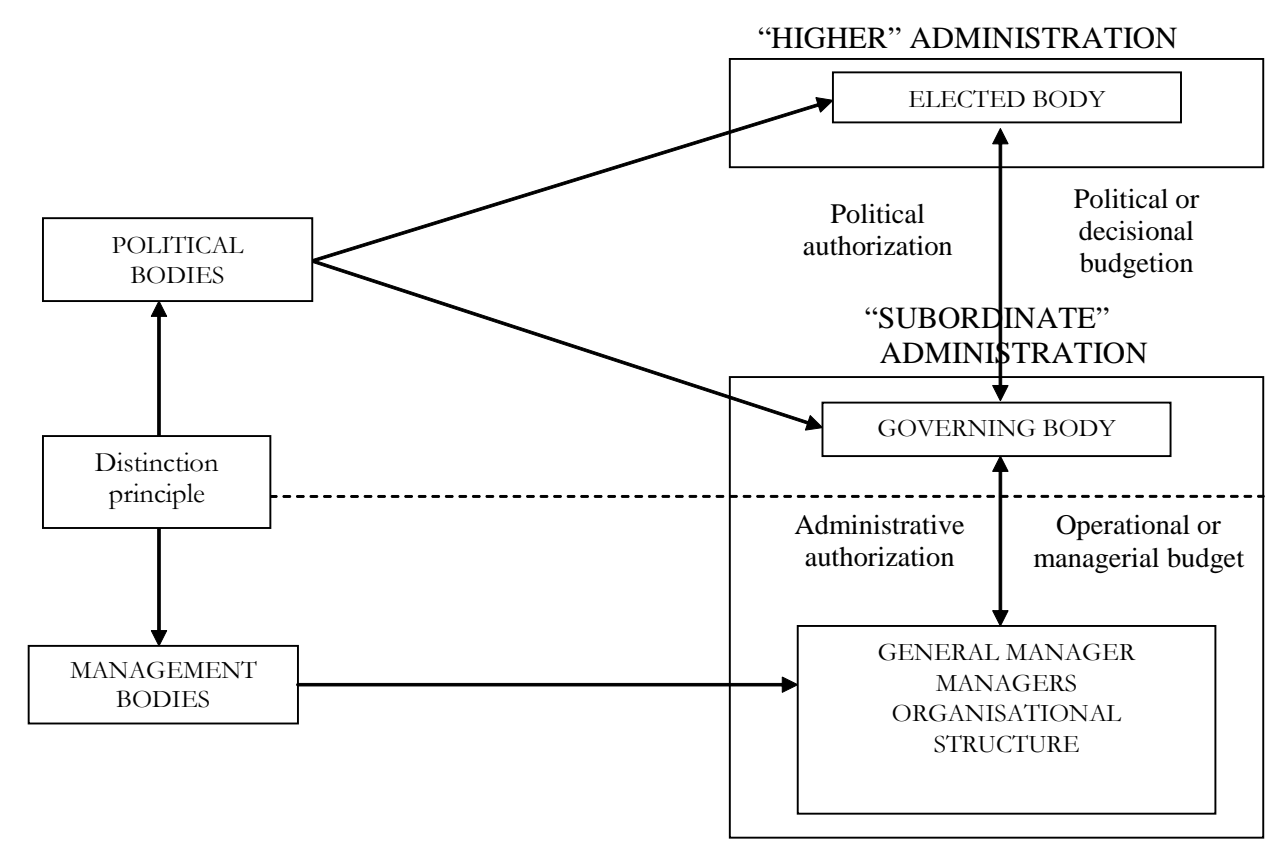

Figure 4. The "distinction" of the authorising function in a single subordinate administration.

${ }^{4}$ See Lgs. Decree 91/2011 Art. 13 and relative Decree from the Ministry for the Economy and Finance of 27 March 2013, published in the Official Gazette 12 April 2013.

${ }^{5}$ See the classification of public administration as referred to in Art. 1, section 2, of Lgs. Decree 165/2001, as well as Art. 1, section 2 of L. 196/2009. 


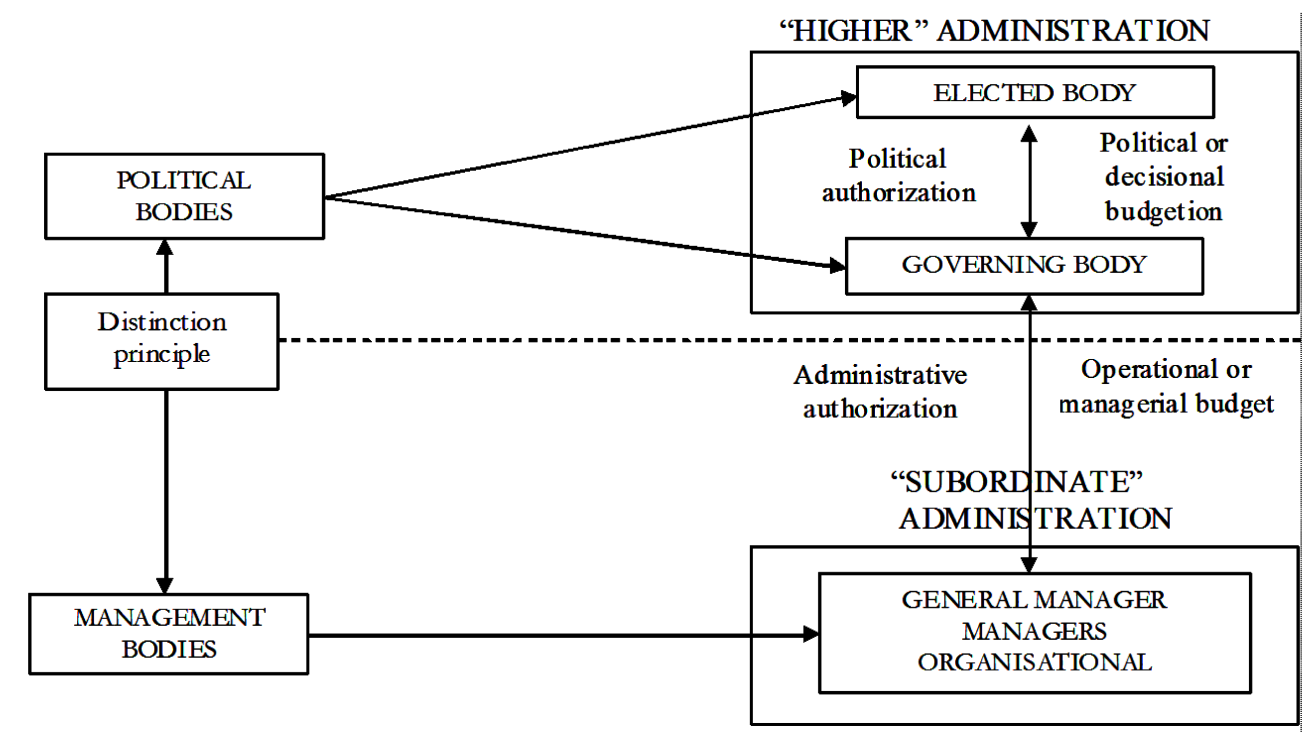

Figure 5. "Distinction" of the authorising function for higher and subordinate administrations.

In these administrations, the "distinction" between politicians and managers shows up not so much in the accounting system used, but more in the following:

- there is a larger component of "service functions" [30] in the "subordinate" administration as compared to the "higher" administration;

- the political bodies of the higher administration influence the appointment of the general manager and the assigning of strategic aims, but do not influence the actual management;

- the general manager is the sole director with autonomy in terms of expenses, which can be delegated to lower management;

- the employment contract of the general manager is never permanent and, therefore, can be revoked at any time.

In this model, the budget is typically an "operational budget", meaning that the resources allocated to the different operational targets assigned to the various managers must be quantified in advance. In this model as well, the budget is a mandatory document which must be available to the public, as it illustrates the way in which political choices are being implemented.

In conclusion, the "distinction" between politicians and top managers requires a legally binding budgeting system to be introduced-one that can convey the authorising function on the budget. Moreover, the choice of accounting model to adopt needs to take into consideration the impact of each model on a company's information system and organization.

The only IPSAS that provides for these rules on the budget is no. 24 .

\section{Content of IPSAS 24 and Constraints of Applicability in Italy}

The title of the IPSAS 24 (Presentation of budget information in the statement) highlights both its content and constraints. The IPSAS 24 integrates IPSAS 1, since it was considered that a financial statement should include a comparison between accounting data and estimates made beforehand. However, the title refers to the term "budget", without there actually being a specific accounting principle on this subject.

In particular, IPSAS 24 does not deal with the budget approval process-it merely requires that administrations which disseminate and make their budgets public provide the following [31]:

a) a comparison between the final balance and the figures listed in the budget;

b) a summary of the political or management reasons for any inconsistency between the final balance and the figures listed in the budget, as referred to in point a);

c) a new statement of the balance figures if they were reached using a different accounting principle from the one used to draw up the budget.

Administrations that do not make their budgets public do not even have to provide the figures requested in the 
IPSAS 24.

The paradox is even more evident in section 29, which considers the comparison of prior figures and balance sheet figures to be essential for the purposes of:

- providing greater transparency in accounting documents and full information concerning the management progress of the body;

- making data which is useful for "social control" and for evaluating the organizational performance of the administration available to the public.

If all public administrations were to publish their budget, this would trigger the twin tracks of managerial "independence and responsibility" and political "direction and responsibility" that are typical of the management model mentioned in paragraph 2.

However, although the IPSAS 24 stresses responsibilising those managing a budget, it does not include any formal requirement on how should be submitted, asserting that it can be provided in an additional information note that is separate from the accounts statement, or it can form an integral part of the financial statement and can be inserted in a specific column for forecasted values placed alongside the accounting values.

Even the nature of budget figures to be compared with the final statement is unclear. In fact, it is envisaged that for each type of audit required by law, it is necessary to consider initial forecasts, i.e., those made before the commencement of the administrative period in question, and the adjusted figures, i.e., the ones illustrating the variations occurring through the year as a result of unforeseen events.

As the nature of the compared forecast figures varies, the information provided and the type of responsibility underlying the reasons for this shift change. In fact:

- the difference between balance sheet values and initial forecasts focuses attention on performance, the efficiency of the administration and the reliability of its programming and budgeting processes;

- the difference between accounting values and adjusted forecasts focuses on definitive allocation, within the limits set by the body approving the budget, and on the legal correctness of those managing the resources.

Nonetheless, one can see how adjusted forecasts are frequently the same as the final accounting statement values. This is because forecasts are monitored constantly and this means that their changes reflect the events within the management and its development.

IPSAS 24 forgets that it is also important to compare initial forecasts with definitive ones. A significant difference in these two values does not only show the reliability of the programming and budgeting processes. It also allows one to understand whether the strategies and policies of those approving the budget were coherent, consequential and suitable.

If changes are made to the accounting principles used, it is essential to refer to IPSAS 3.

Concerning the budget framework, IPSAS 24 refers only to two obvious facts:

- a budget needs to refer to the same period as the accounting statement - this can be an annual period or a period of several years;

- the classification of accounting items in the budget must be the same as in the accounting statement; classifications can be made according to the economic nature of the items, the area of destination of the resources, or specific "missions", i.e., the public aims pursued by the administration.

These vague budget guidelines reintroduce at international level the problems relating to the incoherence between accounting systems that use different models [32].

In particular, in Italy there are administrations with budgets in which items are classified according to their nature, others according to destination, and yet others according to the public aims being pursued [33]. Moreover, sometimes the data classification criterion used to draw up the budget is not the same as the one used in the accounting statement.

The first obstacle to the direct application of IPSAS in Italy, and therefore also of IPSAS 24, is explicitly to be found in the judgment issued by the unified sections of the Court of Audit ${ }^{6}$, according to which:

"It is necessary to specify that the use of IAS or IPSAS is voluntary within the States and authorities concerned; currently in Italy it is possible to apply them to public administration only if transposed by means of specific laws. ... (omissis) ... In addition to this legal aspect, their complete transposition is obstructed by the difficulty in adapting them to the fundamental criteria of our accounting system."

This statement seems to be an outright rejection of IPSAS' application in Italy.

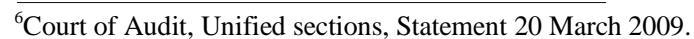


In fact it is not so, particularly following the process of harmonised accounting, whereby several principles are gradually being introduced in Italy, following the adoption of specific laws.

With regard to IPSAS 24, it is possible to see how some IPSAS provisions are already in use thanks to the authorising function of the budget which has always characterised the accounting rules used by public administrations in Italy, in the same way as the "cameral accounting" on which it is based.

In other words, the authorising function of a budget requires that a comparison be made between the account statement and the forecasts. A comparison and calculation of any discrepancies is made for the financial figures, but not for the economic figures. Thus the reference point is only the definitive forecasts, and any differences with the initial forecasts are neglected.

In Italy, the budget for a single year is drawn up in two versions: an "initial" one, drawn up before the start of the administrative period, and an "adjusted" one, following approval of the financial statement for the previous year.

As can be seen from Figure 6, the "initial budget for the year " $n$ " is usually approved before the commencement of year " $n$ "; the financial statement for the year "n-1", is obviously drawn up after the end of the year "n-1". This means that the "initial budget" for the year " $n$ " is defined without knowing exactly the initial values (for ex: receipts, credits, debts, etc.), since these coincide with the accounting values for the year "n-1".

Consequently, there is a need to "update" the "initial budget" once the financial statement has been approved, and a second "adjusted" version of the budget is thus created.

Both types of budget are included in IPSAS 24 since it refers to the terms "original and final budget". However, there are significant differences when comparing the aims of a budget in Italy with IPSAS 24.

In Italy, as already mentioned, budgets are the means with which it is possible to transfer authorising functions between politicians and top managers. As defined by IPSAS 24, a budget is only essential for comparing estimate data with financial account data.

IPSAS 24 expressly states that a budget does not necessarily have to have a legal form such as a law or other administrative act. On the other hand, the Italian legal system qualifies a budget as legally binding and obliges a political body to approve it with a specific legal acts, which, in the case of the State, is a specific law.

\section{Conclusions: Elements to Supplement IPSAS}

The above considerations give rise to three questions, the answers to which should be supplement the international standards:

1) Which body is empowered to draw up the budget and which to approve it?

2) If all of the IPSAS 24 is applied to Italian public administrations, which budget will have the "authorising" function: the original budget or the final one?

3) What classification criteria are used to divide the budget?

With regard to the first question, it should not be forgotten that the programming process in any company is formed, in the context of its in-house organizational procedures, by a "top-down, bottom-up" process. However, in public administrations, this process should involve both the political bodies and management. The result is that the "formation" stage of the budget should not be confused with its "formalisation" stage, i.e., the moment when it acquires a legal status and becomes binding.

This process becomes more complex if the structure of the body concerned is more developed. This is summarised in Figure 7, which refers to a general public administration with a single general manager.

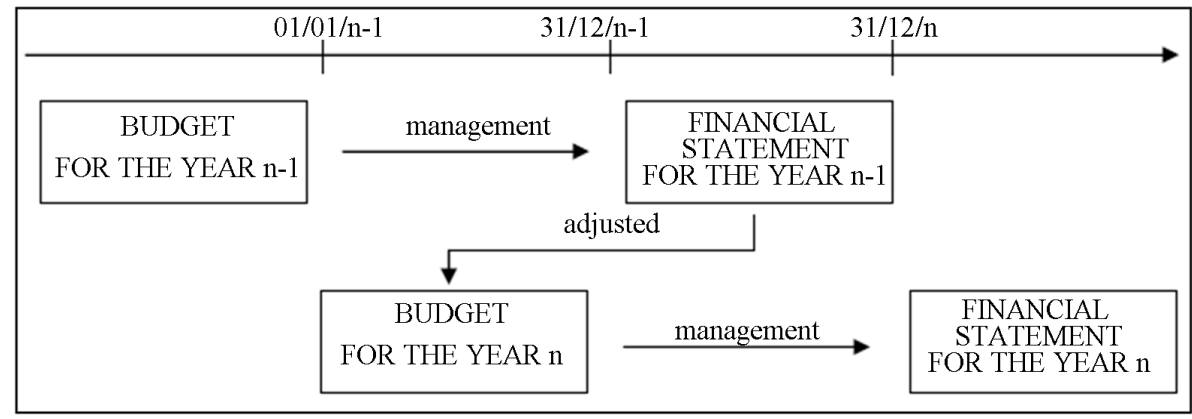

Figure 6. Time line for document approval [34]. 


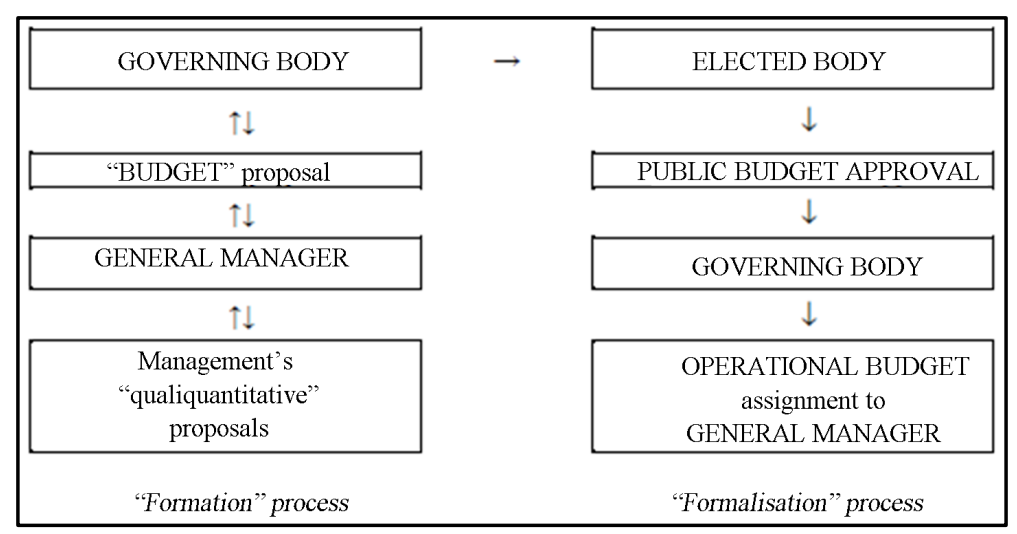

Figure 7. "Formation” and “formalisation” process.

In the management model, the budget "formation" process should start with the proposals put forward by managers and collected by the general manager who, in turn, will create the "budget proposal" both in the form of an "operational budget" and in the form of the "public budget".

After analysing the budget proposal, the governing body decides whether to accept or amend it and draws up the proposal to submit to the elected body. Based on that proposal, a political discussion is launched and the political "budget" will be formalised. It thus becomes the legally and politically binding document that the governing body will refer to as the "operational" budget, which is then assigned to the general manager.

In this case, therefore, a correct accounting principle for the budget should provide:

- the proactive role of managers in the programming process;

- the political level at which the "political budget" is approved;

- the political level at which the "operational budget" is approved;

- the procedures for amending the two budgets over the course of the year;

- the margin of manoeuvre given to management in running the "operational budget".

Of course, when defining these areas, it is necessary to safeguard the organizational autonomy of the single administration.

With regard to the second question, as mentioned in paragraph 4, which covers the content and limits of IPSAS 24, the budget is considered to be a mere tool for comparing estimated data with accounting data, but it does not specify whether checks should apply to the "initial" or "final" forecasts, or even both. This is not an aspect to be ignored in light of the fact that the budget has an authorising function.

It is believed that the choice of data to be compared will vary according to the aim of the checks, i.e.:

- if the aim of the checks is to audit the managerial abilities and the efficiency of the administration, it is useful to compare the financial statement with the "original budget", namely the initial forecasts. In this case, there is an assessment of the causes — be it managerial, ordinary or extraordinary — behind any discrepancies;

- if the focus of the audit is legal correctness, it is necessary to compare the balance sheet with the "final budget", i.e. with the adjusted forecasts. In this case, the audit will focus on compliance with the legal constraints imposed by the management.

In a "pure" managerial model, the authorising function may be performed by the "initial" forecasts. In this case, there is no assessment of the legitimacy of the managers' work, which is considered an essential condition, but rather the professional skills of managers, which forms the basis of the relationship of trust with the political bodies.

Currently in Italy, however, the authorising function of the budget is only performed by the "adjusted" forecasts with, as a result, managers focusing on the legal correctness of the budget, behind which they often try to conceal managerial difficulties or, indeed, inefficiencies.

This does not mean we wish to deny the importance of "adjusted" forecasts, but managerial capability is one thing, legitimate behaviour is another.

With regard to the third question, paragraph 41 of the IPSAS 24 simply states that items in a budget may be classified "on the same basis as is adopted in the financial statements, for example, by economic nature [...], or function [...] or by specific programmes [..]", without taking into account the possibility to divide a budget 
based on organizational structure.

This latter data classification criterion is very important because it allows one to analyse and assess how the allocated resources have been used in the different areas of the administration.

In Italy, with the accounting harmonisation process for public administration, the aim has been to bring together several classification criteria: on the one hand, an "integrated accounting plan"7 has been provided for to allow items to be classified according to their nature, and on the other hand, an articulated functional classification of the budget, divided according to missions and programmes, in accordance with Regulation (EC) No 2223/1996, better known as "SEC 95" [35].

The Italian accounting system also envisages that each programme is assigned to a single centre of responsibility $^{8}$, i.e., to a managerial office. This means that a sum of the resources for various programmes of a single centre of responsibility will give the total resources assigned to a managerial office.

Unfortunately, the first empirical surveys carried out by some authors [36] have pointed to the fact that these programmes are a generic list of project "names", which differ from office to office, to the extent that an assessment of managerial work becomes extremely subjective and can only guarantee formal compliance with legal requirements.

In the light of research, it is considered that the budgets of Italian public administrations already comply with some of the IPSAS 24 provisions. Nonetheless, this standard is entirely unsuitable if it is applied to public administrations where budgets have an authorising function.

These shortfalls are large enough to warrant a specific IPSAS on budgets. That international standard broaden the scope of the information contained in IPSAS 24 and should consider a budget not merely as a means of comparing estimated data with the accounting data, but as an independent document used to regulate the relationships between political bodies and the managers of any public administration.

In particular, such new standard should refer at least to the following:

- the proactive role of management in the programming process. This task, assigned to the top management, cannot be considered as a discretion but must be understood as a duty by management towards the political sphere. It is therefore necessary to identify and define that programming process.

- the political levels at which the "political" budget and the "operational" budget, respectively, are approved. Since it is essential to identify the body which is empowered to "formalise" the budget, one must identify the political level at which the budget becomes legally binding.

- the procedures for amending the two budgets (the "operational" and "public" budgets) over the course of the year. This involves defining the standard procedures to carry out these amendments which modify a document that has already acquired an authorising function.

- the margin of manoeuvre given to management in running the "operational budget". Such margin can vary according to the political budget and, particularly, as a result of a company's organizational structure.

- the authorising function of the budget with reference to the "original budget" or the "final budget" (i.e. assessing which of these two budgets has an authorising function). In order to determine which budget one should refer to, it is necessary to first define the objectives of the check to be carried out and then to establish which data is to be compared.

- the classification criteria for budget data: It is possible to classify such data according to: economic origin; function; specific programme or organizational structure.

On this latter point, it would be appropriate for the international principle to envisage a "European” version [37] [38], which would be coherent with the SEC 95 and COFOG $^{9}$ [39] classifications used at EU level.

\section{Acknowledgements}

We are grateful an anonymous referee for helpful comments. We also wish to thank Kim Humphreys for English editing. All errors are ours.

\section{References}

[1] Roje, G., Vašiček, V. and Hladika, M. (2012) The Perspectives of IPSASs Introduction in Croatian Public Sector. In-

\footnotetext{
${ }^{7}$ See: Lgs. D. 118/2011, Art. 4 and Lgs.D. 91/2011, arts. 5-7.

${ }^{8}$ See: L.196/2009, section 21, section 2; Lgs. D.91/2011, art. 11, section 2; Lgs. D.118/2011, art. 14, comma 2.

${ }^{9}$ COFOG stands for "Classification of Functions of Government".
} 
ternational Journal of Public Sector Performance Management, 2, 25-43.

[2] Schedler, K. and Stäger, L. (1995) La Contabilità Pubblica e la Gestione Finanziaria in Svizzera: Modello, Esperienze e Prospettive. Azienda Pubblica, 2, 345- 358.

[3] Montesinos, V. (1998) Accounting and Business Economics in Spain. The European Accounting Review, 7, 357-380. http://dx.doi.org/10.1080/096381898336330

[4] Pallot, J. (1994) The Development of Accrual-Based for the Government of New Zealand. Advances in International Accounting, 7, 295-299.

[5] Guthrie, J. (1998) Application of Accrual Accounting in the Australian Public Sector-Rhetoric or Reality? Financial Accountability \& Management, 14, 1-19. http://dx.doi.org/10.1111/1468-0408.00047

[6] Borgonovi, E. (1996) Principi e Sistemi Aziendali per le Amministrazioni Pubbliche. Egea, Milano, 245.

[7] Wilson, T.W. (1887) The Study of Administration. Political Science Quarterly, 2, 210. http://dx.doi.org/10.2307/2139277

[8] Richards, D. and Smith, M.J. (2004) Interpreting the World of Political Elites. Public Administration, 82, 777-800. http://dx.doi.org/10.1111/j.0033-3298.2004.00419.x

[9] Anthony, R.N. and Young, D.W. (2003) Management Control in Non Profit Organization. 7 Edition, McGraw-Hill.

[10] Flamholtz, E.G. (1996) Effective Management Control. Theory and Practice. Kluwer Academic Publishers. http://dx.doi.org/10.1007/978-1-4613-1359-5

[11] Peters, B.G. (1991) La Pubblica Amministrazione: Un’ Analisi Comparata. Il Mulino, Bologna.

[12] Foster, C.D. (2001) The Civil Service under Stress: The Fall in Civil Service Power and Authority. Public Administration, 79, 725-749. http://dx.doi.org/10.1111/1467-9299.00277

[13] Battini, S. (2000) Il Personale. In: Cassese, S., Ed., Trattato di Diritto Amministrativo. Diritto Amministrativo Generale, Tomo Primo, Giufffrè, Milano.

[14] Paoloni, M. and Grandis, F.G. (2007) La Dimensione Aziendale delle Amministrazioni Pubbliche. Giappichelli, Torino, 143.

[15] Fisichella, D. (2003) Lineamenti di Scienza Politica. Carocci, Roma.

[16] Dunleavy, P. and Hood, C. (1994) From Old Public Administration to New Public Management. Public Money and Management, 14, 9-16. http://dx.doi.org/10.1080/09540969409387823

[17] Kooiman, J. (2003) Governing as Governance. Sage, London.

[18] Gray, A. and Jenkins, B. (1995) From Public Administration to Public Management; Reassessing a Revolution? Public Administration, 73, 75-99. http://dx.doi.org/10.1111/j.1467-9299.1995.tb00818.x

[19] Zappa, G. and Marcantonio, A. (1954) Ragioneria Applicata alle Aziende Pubbliche. Primi Principi, Giuffrè, Milano.

[20] Barzelay, M. (2001) The New Public Management: Improving Research and Policy Dialogue. University of California Press, Barkeley.

[21] Masini, C. (1970) Lavoro e Risparmio. Utet, Torino.

[22] Hopwood, A.G. and Miller, P. (1994) Accounting as Social and Institutional Practice. Cambridge University Press, Cambridge.

[23] Owen, D. (1992) Green Reporting: Accountancy and the Challenge of Nineties. Chapman and Hall, London.

[24] Gray, A., Bebbington, J. and Walter, S.D. (1993) Accounting for the Environment. Paul Chapman Publishing, London.

[25] Lapsley, I. (1992) Management Accounting in the Public Sector. In: Henley, D., Likierman, A., Perrin, J., Evans, M. and Whiteoak, J., Eds., Public Sector Accounting and Financial Control, Chapman and Hall, London.

[26] Bucellato, A. (2001) La Funzione del Programma Elettorale per il Governo delle Aziende Pubbliche. In: Annali della Facoltà di Economia di Cagliari, Franco Angeli, Milano.

[27] Giovanelli, L. (1997) Il Controllo Come Guida della Gestione. In: Il Controllo di Gestione nelle Amministrazioni Pubbliche, Maggioli, Rimini.

[28] Grandis, F.G. (2006) Le Ambiguità nelle Riforme dei Sistemi Contabili Pubblici. Quaderni monografici Rirea, No. 47, RIREA, Roma, 24.

[29] Schrott, J. (1856) Lehrbuch der Allgemeinen Verrechnungswissenschaft. Friedric Rohlicek, Prag.

[30] Borgonovi, E. (2004) Principi Contabili: Anche Nell’Amministrazione Pubblica? Azienda Pubblica, 17, 173-178.

[31] Müller, T. and Berger, M. (2012) IPSAS Explained. A Summary of International Public Sector Accounting Standards. 2nd Edition, Wiley, Hoboken.

[32] Ponzo, S. (2009) Il Sistema delle Informazioni per la Pianificazione e il Controllo nelle Pubblicheamministrazioni. Giuffrè, 
Milano, 174-175.

[33] Farneti, G. and Pozzoli, S. (2005) Principi e Sistemi Contabili Negli Enti Locali. Il Panorama Internazionale, le Prospettive in Italia. Franco Angeli, Milano.

[34] Paoloni, M. and Grandis, F.G. (2007) La Dimensione Aziendale delle Amministrazioni Pubbliche. Giappichelli, Torino, 404.

[35] Mazzotta, B. and Passaro, A. (2008) L’Armonizzazione Contabile in Italia: Stato Dell'Arte e Tendenze Evolutive nella Prospettiva della Ragioneria Generale dello Stato. In: D’AMORE, M., Ed., The Harmonization of Government Accounting and the Role of IPSAS, McGraw-Hill, Milano.

[36] Luciani, N. (2002) L’efficienza della Pubblica Amministrazione Misurata dal Saldo di Bilancio? Idee da una Recente Riforma del Bilancio dello Stato, in Italia. Economia Società e Istituzioni, 14, 285-310.

[37] Report, E.C. (2013) Towards Implementing Harmonised Public Sector Accounting Standards in Member States. The Suitability of IPSAS for the Member States, Brussels.

[38] Aceituno, F., Valeriano, J., Bolivar, R. and Pedro, M. (2006) The Conceptual Framework Concept and the Allocation of Incomes in the Consolidated Entity: Its Impact on Financial Ratios. International Journal of Commerce and Management, 16, 95-115. http://dx.doi.org/10.1108/10569210680000210

[39] Fortunato, M. and Lagravinese, R. (2008) La Classificazione Economica e Funzionale della Spesa delle Regioni: Il Caso della Regione Lazio. Quaderni di Economia Regionale, 8. 